[Nicholson, T. (2009). Achieving Equity for Māori Children in Reading by 2020. New Zealand Annual Review of Education, 18, 159-182]

\section{Achieving Equity for Māori Children in Reading by $2020^{1}$}

\section{TOM NICHOLSON}

\section{Abstract:}

One of the biggest challenges in this country is to raise Māori achievement in literacy. Māori are the first nation, and it seems unjust that their literacy levels are not on a par with those of Pakeha despite massive efforts to close this gap. In this review it will be argued that Māori children in New Zealand fail to receive a "fair deal" (equity) in learning to read for a number of reasons, but primarily because our schools employ the wrong method of teaching reading. They do not receive a fair deal in other curriculum areas as well, possibly because the same philosophical assumptions about learning that drive our present teaching of reading are also prominent in other subject areas such as science and mathematics (see Matthews, 1995). However, this review will restrict its attention to reading.

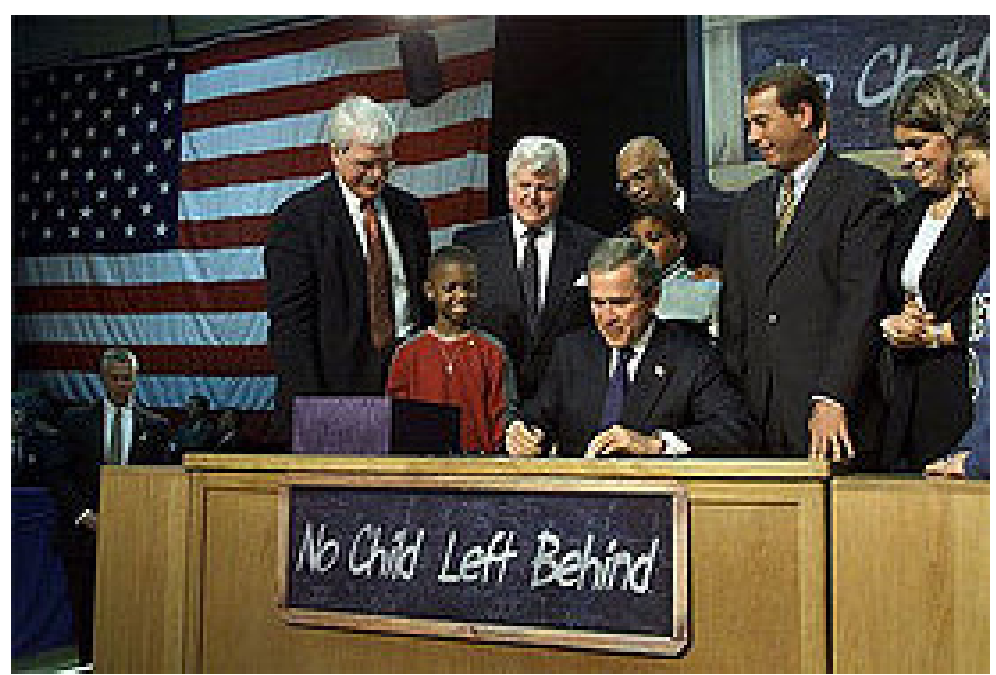

160 Tom Nicholson

n 2002 the President of the United States launched new legislation called "No Child Left Behind" (NCLB). The purpose of the Act was to lift academic standards, especially in reading. The government asked individual states to set their own achievement standards and design assessments to see if the standards were being achieved. Funding for reading instruction increased 400 percent. As part of the NCLB funding, a program called Reading First was initiated. It was designed to ensure that all children could read at or above grade level by the end of third grade. Schools that accessed Reading First funding were required to use reading instruction based on "scientifically based" research.

In 2008, six years after the introduction of NCLB, a "Reading First Impact Study Interim Report" from the Department of Education, using data collected from 12 states covering the first three years of school, stated that Reading First results were "not statistically significant" (Gamse et al., 2008, p. ix). The United States Education Secretary in 2008 commented that "moving the needle on reading is a hard thing to do.... I don't think anyone's going to assert that the cure will be less focus and fewer resources" (Toppo, 2008).

\section{The Literacy Gap in New Zealand}

The literacy gap has also been problematic in New Zealand schools for a long time. In the early '80s, Ramsay and others wrote a report about South Auckland schools called "Tomorrow May Be Too Late" (Ramsay et al., 1981). The report found that in 27 primary, intermediate, and secondary schools in that area, between 45 and 76 percent of their pupils showed reading attainment reading below the 30 th percentile - i.e., below the "the lower end of average" (Stanines 1-4). Many interventions later and we are still struggling to "raise the needle" in reading in this disadvantaged area of the country.

In 1999 the New Zealand Government announced its National Literacy and Numeracy Strategy with its goal that "by 2005 every child turning nine will be able to read, write, and do maths for success" (Ministry of Education, 1999). These efforts also appear to have been less than effective, in that our literacy scores barely changed and our ranking went backwards between 2001 and 2006 (Chamberlain, 2006). The 2006 Progress in International Reading Literacy Study (PIRLS) survey found that New Zealand ranked 24th out of the 45 participating countries (Mullis, Martin, Kennedy, \& Fory, 2007). This was a fall in 
ranking from a previous 2001 survey where New Zealand had ranked 13th (Mullis, Martin, Gonzalez, \& Kennedy, 2003).

The 2006 PIRLS results contrast sharply with those of the same type of survey in 1970 when New Zealand came first, ahead of USA, Scotland and England (Thorndike, 1973). In that survey, results were not produced separately for Māori and Pakeha, but the standard deviation for all pupils in the study was not unduly large, when compared with the average score. This indicated that there were no great inequities, no great gap between the top and bottom readers. If there had been a gap between Māori and Pakeha it would have showed in a larger standard deviation, but it did not. The recent surveys show a large gap, and when the data are classified by ethnicity, the pupils most likely to be in "the tail" are Māori.

\section{Are too many $M$ ori being left behind?}

New Zealand is "a tale of two cities." Since the 1990s it has had the reputation of producing some of the best readers in the OECD, but also some of the worst (Organisation for Economic Cooperation and Development, 1998). Those at the bottom end are minority group children like Māori and Pacific students, and children of the poor. The 2006 PIRLS results confirmed that New Zealand still has a large literacy gap between the best and worst readers (Tunmer et al., in press).

For Māori pupils the extent of the gap can be seen in their leaving statistics. In 2005, more than half (53 percent) of Māori boys left school without a Level 1 qualification in the National Certificate of Educational Achievement (NCEA), compared with 20 percent of Pakeha boys (Ministry of Education, 2006; "Half of Māori boys", 2007). Pakeha students are more than twice as likely as Māori to get a University Entrance qualification (Ministry of Social Development, 2008). In 2006, 15 percent of Māori and 17 percent of Pacific students gained University Entrance qualifications, compared with 63 percent of Asians and 41 percent of Europeans (Strategy and System Performance, 2007, Table 10.1). Narrowing the literacy gap is important not just for educational reasons but for economic reasons as well, since achievement differences between Pakeha and Māori are linked to income inequalities in the labour market (Maani, 2004)

Why do we have such a literacy gap? In theory, New Zealand should be well placed to display a more equitable level of reading achievement. We have a centralised education system with only 4.2 million people in the whole country to look after. We are not like highly-populated countries such as China or India, or even England or the USA, where there is a decentralised system and considerable variation in resources. We have trained teachers, well set-up schools, free reading materials for children, free teacher manuals, and a monitoring agency, the Education Review Office (ERO) to ensure standards are high. We pour so much money into education, yet we keep slipping behind.

Lock and Gibson (2008) undertook an analysis of New Zealand data from a recent OECD Programme for International Student Assessment (PISA) survey of reading, mathematics, and science. They found that the main risk factors in school achievement were: being male, being Māori, and being in a low decile school. ${ }^{2}$ Socioeconomic status was a big contributor to the poor results for Māori. The analysis showed that 41 percent of Pakeha students were in high decile schools compared with only 18 percent of Māori. Differences in school decile contributed 11 percent to the achievement gap between Pakeha and Māori. It seems that Māori pay a small but significant price for attending low-decile schools.

These statistics should not be seen as advancing deficit theory. As Clark (2006) has pointed out, the closing of the literacy gap is a far more complex task. It is not about blaming Māori parents for their children's achievement in school, as if parental influence was the most important factor in their learning. It has been argued that our poorest readers tend to be "boys, Māori, Pacific Islanders, and children from poor and bookless homes" (Smith \& Elley, 1997, p. 114) which on first sight suggests that the problems of Māori children may be due to their parents not taking advantage of opportunities for bedtime reading and other literacy activities, commonplace in middle class families. An example of the effects of differences in literacy environments is a study by Gibbons (1981) of some preschool children who had been read to every night since they were 12 months old, compared with others who had been read to very little. She called them 1,000 book children and 100 book children. She found that the 1,000 book preschool children had a much better knowledge of book concepts, book language, and the letters of the alphabet. The 1,000 book children could not read, but they appeared to have good pre-reading skills and this may have been due to the hours of exposure to bedtime reading at home.

The question is: To what extent is a highly literate environment a major stimulus to learning to read? There is much research to say that reading books to children helps improve their vocabulary and their 
understanding of how books work, but does not actually teach them to read. In the school setting, Gibbs and Nicholson (1999) found no effects of repeated tellings of stories on Year 1 New Zealand children's reading. Scarborough and Dobrich (1994) in an international (and controversial) meta-analysis of 31 studies, found parent story book reading contributed 8 percent to later reading achievement by the child. This is a small but significant positive for children from literate home environments, but it is only part of the picture.

Given the research on reading stories to children, in relation to Māori children, it is hard to accept that home literacy environment is a major factor in holding them back. There is some evidence (although it is hard to get actual figures) that Māori in the 1830s were more literate than Europeans, even though they lacked literacy resources (Simon, 1998). They were certainly not read to every night when they were children, yet they still learned to read. As one writer put it, "The Maoris not only taught each other to read but appear to have learnt to read their own language with surprising speed and ease" (Parr, 1961, p. 438). Another indicator of Māori literacy was the amount of letter writing carried on: "The Maoris corresponded by letter almost as regularly as the Europeans, to the surprise of one missionary who saw a bag containing nearly 20 native letters being carried in a canoe on the Wanganui River, the bearer being 'a regular postman', and of a visitor to the Bay of Islands Post Office who saw there a bundle of native letters a foot square" (p. 219). Simon (1998) notes that the extent of Māori literacy in the 1830s is debated by scholars, but even so, these notes suggest that Māori literacy was impressive in colonial times.

Another reason why the family literacy explanation is not an entirely plausible explanation is that we already have many successful Māori politicians, writers, lawyers and other professionals and business people who have come from poor backgrounds, yet have been able to achieve high levels of literacy. One's socioeconomic situation is not on its own an acceptable reason for low Māori educational achievement.

Another source of blame is the pupils themselves. It can be argued, for example, that Māori pupils, and struggler readers in general, avoid reading and don't want to learn. They are often disruptive and uncooperative in class. The problem is that we don't know if poor behaviour and negative attitudes to school and to reading are a consequence of having to struggle with reading or a cause of poor reading. The research suggests it is a consequence (Stanovich, 1986; Chapman, Tunmer, \& Prochnow, 1998b; Nicholson \& McGregor, 2008).
A further source of blame (or praise) is the teacher. When I first started teaching I did not know much about reading and it came as a surprise to me that some of my pupils were struggling. I remember going back to my University library to look for books that might help, and making resources to assist those in need. As a novice teacher I could teach average and good readers, but I did not know how to help poor readers. After five years of teaching I still was not confident about helping poor readers, even though I thought I was a reasonably good teacher.

Gough (1996) argues that good teachers will teach children to read no matter what method they use, just because they are good at what they do. There is some doubt about this. Teaching poor readers requires specialist skills. Even if it were true that good teachers teach children to read no matter what the method, the problem is that we do not have a surplus of good teachers in this country.

The question is: How can we help the vast majority of teachers, especially average and below average teachers, to be better? As a university teacher educator I know how difficult it is to teach trainees to help pupils who are struggling to read. Most teacher trainees want to "survive". Their main goal is to teach a lesson to a whole class without having management problems. This means a university reading course has to focus on whole group teaching methods which are required in every classroom. Helping individuals with reading problems is not a priority for the first year or so of teaching for a trainee. On the other hand some of my students volunteer to work in our university reading clinic outside class hours, so perhaps the real problem is that our training programmes do not give enough time to literacy and other curriculum difficulties.

How much time do regular teachers give to struggling readers? Henson (1991) interviewed classroom teachers in Years 4-6 and noted that many teachers felt they gave too much time to the strugglers in their classes. He did not ask them how much time. The reality, however, is that most teachers are unable to give much time at all to individual children - not even the strugglers. In support of this claim, Henson reported that "The majority of teachers expressed concern that they were not able to cater for these pupils as well as they would wish. Particular worries were lack of time, perceived lack of knowledge about appropriate programmes, and lack of suitable materials." One teacher commented, "Probably don't have much success. Try to make them feel happy to come to school" (1991, p. 12) 


\section{Competing Paradigms}

In light of the difficulties in helping children on a one-to-one basis in the classroom, perhaps the only realistic way for teachers to close the literacy gap is to have available in their armoury an alternate way of teaching that might be better suited when the mainstream approach, whole language, is not working well. This leads to the vexed question of which reading method is more effective. There are really only two main methods of teaching reading in English at the present time: whole language and phonics. As Gough (1996) points out, whole language is the popular approach in schools. In the United States it is disliked by the public but embraced by most teachers.

This seems to be the case in this country as well. Many of our teachers believe whole language works very well. In support of this is a report by Hughes (1999). She surveyed 92 primary school teachers. Nearly all teachers in the survey believed they were effective teachers of reading. Virtually none thought they were ineffective. Their beliefs about reading were strongly aligned with whole language. For example, when asked to list advantages of whole language teaching, 84 percent responded. When asked to list advantages of phonics, only 49 percent responded.

The arguments for and against whole language and phonics have been well rehearsed (Tunmer, Prochnow, \& Chapman, 2003; Pearson, 2006; Tunmer \& Nicholson, in press; Nicholson \& Tunmer, in press). The problems with each method were well described by Gough (1996). Drawing a parallel from Shakespeare's Romeo and Juliet, his paper was titled, "A pox on both your houses". The main argument against whole language teaching is the assumption that children will learn to decode simply by reading. Whole language teachers encourage children to guess at words rather than decode them, thinking that in this way their pupils will become able to decode by induction. This can be seen in shared and guided reading activities. Every teacher of whole language does this every day. Decoding is not explicitly taught. Children are taught to read words by predicting what they will be and sampling just the initial letters of the word.

The advantages of whole language are that teachers read children's literature to the class every day, they share interesting books with the class, and they guide groups of children as they read a story or article. The downside of this approach is that many pupils, as many as one in four, do not learn to decode this way.
The advantages of phonics are that it enlightens pupils that English writing is based on the alphabetic principle (that is, it is a written form of the spoken word), it empowers students to read "in loco parentis" by teaching them rules for decoding words, and it encourages pupils to sound out words rather than guessing them. Another plus for phonics with Māori children is that it complements they way they learn to read Te Reo. The Māori language writing system is very transparent phonologically. It is easy to learn to read with a phonics approach. The counter-argument here is the question: What will happen when Māori children have to read irregularly spelled English words? Won't this have a negative effect? It might, but only if we insist that phonics can enable a child to read every word, when clearly this is not possible.

The disadvantage of phonics for reading English is that it teaches rules for sounding out words, but the rules are not 100 percent reliable, that is, they are heuristics. The heuristics work much of the time, yet not all the time. This is because the English language has borrowed from other languages over a long period of time and these languages have different decoding rules. Also, many words have become irregular, in that they are no longer spelt exactly as they are pronounced. Unfortunately many of the irregular words are extremely common (e.g., come, of, is). When the main phonics rules do not work, the child is left adrift.

Even if pupils know a large number of rules, it is not anywhere near the number they need to learn in order to be able to decipher words fluently and accurately. Many rules need to be inductively worked out through extensive reading. Sounding out words can also be slow, and as a result the pupil can lose the meaning of the text. This is aside from the fact that phonics is often regarded as dull and boring (Harrison \& Gough, 1996).

Which method is more effective? I would argue that research favours phonics, but this does not seem to have had any significant effect on literacy policy in this country. This may be because New Zealand teachers traditionally have had a love affair with whole language teaching (Elley, 1994). It may also be because there is a strong belief that whole language is the better way to go, if it is taught properly (the term used is "best practice"), despite the fact that meta-analyses of reading methods favour phonics over whole language. Hattie (2009) summarised 14 meta-analyses involving 6,000 students and concluded that the effectiveness of phonics was quite strong (average effect size $0.60)$. He concluded "Overall, phonics instruction is powerful in the process of learning to read - both for reading skills and for reading 
comprehension" (p. 134). He also summarised four meta-analyses of whole language teaching involving over 600 students and found, by way of contrast, that it was not effective at all (average effect size 0.06).

For whole language he concluded:

In summary, whole language programs have negligible effects on learning to read - be it on word recognition or on comprehension. Such methods might be of value to later reading but certainly not for the processes of learning to read; it appears that strategies of reading need to be deliberately taught, especially to students struggling to read. (p. 138)

It might be argued that teaching vocabulary (average effect size 0.67 ) and repeated reading (average effect size also 0.67) are also mentioned in Hattie (2009), and are also important. But these results are not problematic, in that reading comprehension requires all these elements: decoding skill, vocabulary, and fluency. They are all important but none of them on their own are sufficient. The point Hattie makes is that phonics appears to be more effective than whole language for teaching decoding, and that implies a relatively greater impact on reading comprehension.

What is it that separates whole language from phonics teaching? A major belief of whole language is that good readers predict words and sample from the print. They see reading as a "psycholinguistic guessing game" (Goodman, 1965). To be fair, whole language does use several types of information to read words, including semantic cues, syntactic cues, and grapho-phonic cues. The criticism of this strategy is that phonics is seen by whole language teachers as playing a minor role in the process of using these information sources (Thompson, 1993; Tunmer \& Nicholson, in press). A problematic for the whole language approach is that research shows good readers do not rely on semantic and syntactic cues for word reading. This is something that only beginners and poor readers do. Good readers can read words just as well in lists as in context (Nicholson, 1991). Poor readers have to guess; good readers need not. Good readers are good decoders, poor readers are not. The whole language emphasis on prediction, stressing that it is a major strategy for reading words, does not help poor readers. Poor readers need to learn word decoding strategies to the point where they can use context clues to guess the meanings of words without having to rely on such clues. What the teacher is really saying to a poor reader when she encourages guessing is that guessing is what makes good readers good, that good readers are lucky, because they can guess the meaning of words, but that they are unlucky because their guesses often do not work out. The problem with this way of thinking for the poor reader is that it is telling them success in life is a matter of luck, not hard work, and that they will never be any good because they are unlucky.

Phonics does not advocate sophisticated guessing in the way that whole language promotes. It stresses that you can decode every word without guessing, and thus can be empowering. It teaches children that there are rules they can apply to decoding words (Nicholson, 2005, 2006a). Decoding words is not a matter of luck but of knowing what the rules are. The rules may not always work completely because English spelling is not completely phonemic, but they often do work

\section{Not a level playing field}

Whole language might work better for children if Year 1 of school was a level playing field, but this is certainly not the case. Māori and Pacific children, who are predominantly from low-decile schools, start school with significantly fewer pre-reading skills than middle class children (Nicholson, 1997, 2003, 2008). The term "literate cultural capital" (LCC) has been used to reflect these differences in home literacy resources between children from low-income and middle-income backgrounds.

The whole language philosophy relies heavily on children having good levels of these pre-reading skills. When they are not present, the task of learning to read becomes difficult. Imagine a group of children sitting on the mat while the teacher shares a book (e.g., "Greedy Cat") with them. Some children in the group, those with good knowledge of the alphabet and a good understanding that spoken words are made up of sounds (phonemic awareness) will look at a word like CAT and match up the letters with their existing knowledge of letters and sounds. They will begin to work out how to decipher the word as the spoken word /kat/ and be in a good position to generalise this knowledge to similar words like MAT and HAT.

At the opposite extreme, a pupil with no alphabet knowledge and with no understanding that words are made of little sounds called phonemes will have no idea that CAT has anything to do with the spoken word $/ \mathrm{kat} /$. This child is probably from a poor background and likely to be Māori or Pacific. In this way, whole language teaching privileges children with high levels of LCC and makes it difficult for children with low levels of LCC to induce the letter sound rules of English writing. 
Phonics, in contrast, makes no distinction between high and low levels of LCC. It has a definite scope and sequence. It teaches the letter-sound rules directly. Teaching one letter sound rule every school day will enable the 5-year-old to learn all the basic rules after eight weeks of school, before the end of the first term (there are 40 grapheme-phoneme rules to learn in order to decode the most common words - the Anglo-Saxon words of English).

Instruction in phonemic awareness and phonics, in conjunction with regular whole language teaching, would seem to give Māori children a better prognosis for learning to read. In support of this hypothesis, Tunmer, Chapman, and Prochnow (2003) found that when they added more phonological teaching to the classroom programme in the first two years of school, the initial gap between Pakeha and Māori children at school entry had closed by the end of Year 2. This is a remarkable result.

\section{A Possible Accommodation}

If phonics was more effective than the whole language approach, then we would expect that countries where phonics is taught would achieve higher scores in international comparisons. However, Scotland is a country that has traditionally taught phonics and yet its reading attainment in recent international surveys is similar to that of New Zealand. A difficulty in making this comparison is that the population of Scotland is 98 percent white and does not have an ethnic mix comparable to that of New Zealand, so it is hard to equate the two countries. The Scottish way of teaching phonics does seem to have different effects. Thompson (2001) found that New Zealand children matched in reading level with Scottish children read in different ways. New Zealand children were quicker, and less likely to sound out words. The way traditional phonics is taught in Scotland has also been challenged as not explicit enough and not effective enough (Johnston \& Watson, 2007)

The two main methods of teaching reading have their pros and cons, but together they would make a formidable team. Neither whole language nor phonics is sufficient on its own to help children learn to read English writing. At the moment we rely heavily on the whole language method in our schools, when clearly this is going to disadvantage many pupils. We need to give phonics teaching a much higher profile in the classroom reading program in schools, so that it becomes a key part of the literacy hour (or two hours). It requires just as much teacher time given to it as do the whole language strategies of shared book and guided reading.

Phonics instruction does not need to be long term. A short period of phonics instruction in Year 1 can be very effective (Johnston \& Watson, 2007). The literacy hour could start with 30 minutes of whole class instruction. First, 10 minutes of phonemic awareness instruction to raise awareness of sounds in spoken words. Second, 10 minutes on teaching phonics. Third, 10 minutes of shared book reading with the class. After that, children would break into groups, where there would be more opportunity to consolidate phonics by having one group do "word work". The four blocks technique would have each small group working for 20 minutes doing either guided reading with the teacher, personal reading, writing, or word work.

In the phonics part of the lesson, teaching one phoneme a day would work well. In this way the class would cover 40 English letter-sound rules in 8 weeks. After teaching the particular phoneme for the day, the teacher could draw the attention of the class to examples of the phoneme in the shared book reading (e.g., the A in CAT in the story "Greedy Cat") so that pupils could see the way the phoneme rule relates to words in the shared book.

\section{Phonics in Early Childhood}

If it was not possible to bring more phonics to the teaching of reading in Year 1 and beyond, then another option would be to teach pre-reading skills in kindergarten, especially phonemic awareness. The gap in pre-reading skills between middle class and lower class pupils could be closed if pre-reading skills were part of the early childhood curriculum. If early childhood educators taught phonemic awareness, a major breakthrough might be possible.

This should especially be the case for children in low-decile areas, many of whom are Māori children. A simple technique called Turtletalk (Gough \& Lee, 2007) trains children to pronounce each phoneme of a word as slowly as possible, e.g., t-ur-t-1, t-r-ai-n, s-o-k-s, etc. Once phoneme awareness is in place, learning how to relate phonemes to alphabetic letters (though not as essential as phoneme awareness) would be extremely helpful. Apart from phoneme awareness, knowing the sounds of the letters of the alphabet is one of the best predictors that we have of learning to read (Stuart, 1999; Clay, 1982; Nicholson, 2003).

Even if we change reading methods to include more phonics, we still have to consider whether we can raise our expectations of Māori 
children. There are, to my knowledge, no examples of decile 1 schools performing in reading at the same levels as decile 10 schools, so we have a "glass ceiling" effect operating in terms of Māori and Pacific reading achievement. Instead, research suggests that children in decile 10 schools will be three years ahead of children in decile 1 schools in reading accuracy, and two years ahead in comprehension by the time they are 10 years old (Nicholson, 2003). There would appear to be no reason why a decile 1 school could not be reading at the same level as a decile 10 school, if teaching can be differentiated so that we can teach differently according to the needs of students. It is obviously more challenging in that the home literacy environments differ significantly. This is where adding phonemic teaching and phonics to the whole language reading program of a low-decile school can compensate for differences in home literacy resources (LCC).

Changing the classroom method of instruction is crucial but it will not be enough. We also have to look at intervention programs for Māori children, and indeed for all children in low decile schools. Reading Recovery is the only major remedial programme currently on offer for 6-year-old children who are failing to read. But it would appear that its long term effects are not large (Glynn, Crooks, Bethune, Ballard, \& Smith, 1989; Chapman, Tunmer, \& Prochnow, 1998a; Tunmer, Chapman, Ryan, \& Prochnow, 1998). Changes will be needed so that Reading Recovery is more effective for 6-year-old struggling readers.

Several research projects in the area have been funded by the Ministry of Education over the last decade. The recent 2006 Literacy Professional Development Projects involved giving professional development training to teachers in over a hundred schools. However, external validity suffered through not having control groups (English, Bareta, \& Winthrop, 2008). My own reading of the 2006 evaluation results was that Māori children improved but Pakeha children improved even more, thus increasing the literacy gap rather than reducing it. In support of this observation, an independent evaluation of the 2004 Literacy Professional Development Project (McDowall, Cameron, Dingle, Gilmore, \& MacGibbon, 2007) concluded that:

When considering only those who started in the group with initially low reading achievement both Māori and Pacific groups made significantly lower shifts and had significantly lower final scores than their New Zealand European counterparts. These findings suggest that if the primary goal is to reduce differences in achievement by ethnicity different types of intervention may be needed. (p. 3 )
Another project that appeared to have good results but overstated them was "Picking up the Pace", a school professional development project contracted to researchers at the University of Auckland, and aimed at raising the educational achievement of children in the generally low decile area of South Auckland. The main hypothesis of the study was that if teachers were trained to make accurate assessments of children's reading levels, and target their whole language instruction appropriately, then reading results would come up to the national average. As with the Literacy Professional Development Projects there was no randomised control group. Because of this design flaw, both Nash (2003) and Harker (2003) have questioned the ambitious claims of the project.

Notwithstanding these criticisms, the research has been published. McNaughton, Phillips, and McDonald (2003) tracked the reading progress of children in low decile schools which were 91 percent Māori or Pacific. They found that children in whole language classrooms in low decile schools learned letter names and sounds by the end of Year 1 without any extra phonics. A problem, though, is that children in high decile schools already know their letter names and sounds at the start of Year 1 (Nicholson, 2003). Another study by Phillips, McNaughton, \& McDonald (2004) found that a whole language intervention raised word reading levels by the end of Year 1, something that had not occurred in the normal whole language setting. This was positive, but problematic, in that children were still not reading at their chronological age level.

Lai, McNaughton, Amituanai-Toloa, Turner, \& Hsiao (2009) reported a three-year study of Year 4-6 children in low decile schools, using a whole language intervention, which showed positive effects for reading comprehension. The results showed that children at the end of the three years were reading at stanine 4 levels, which is the low end of the average range. This is a positive finding for whole language teaching, but on the negative side it could be argued that here is whole language at its best - lots of research help and training has enabled these children to become mediocre readers. It illustrates well the glass ceiling, the best that Māori and Pacific children can hope for under the present system.

The Te Kotahitanga Project, funded by the Ministry of Education is another example of the "we think we have the solution" approach to researching Māori achievement. The project aimed to assess the effect of a professional development program designed to change teachers' expectations of Māori pupils, in particular, to reduce or eliminate deficit theorising about Māori achievement (Bishop, Berryman, Cavanagh \& 
Teddy, 2007). Once again, the research design did not allow a comparison with a control intervention (such as one which simply improved teachers' content knowledge about literacy and mathematics), which would have been an interesting test of deficit theory. Instead, the study compared the intervention group with a group of pupils in the same schools whose teachers did not receive the professional development. Openshaw (2007) has critiqued Te Kotahitanga and questioned whether deficit theory is an adequate explanation of the lack of equity between Pakeha and Māori achievement. Clark (2006) has also questioned the validity of deficit theory, which in these studies refers to teacher expectations, as a way to explain cultural and social inequities in educational achievement.

My own experience in doing controlled studies with children in decile 1 schools is that positive results are attainable, but that marked improvements are difficult to achieve when compared with those of a randomised control group (Castle, Riach, \& Nicholson, 1994; Nicholson, 1997). In a two-year intervention study with over 100 poor readers (almost all Māori and Pacific children from decile 1 primary and intermediate schools), the results showed that reading tuition, once a week for 40 minutes during school hours, made a positive difference for children who were behind in reading. The control group, which received instruction in mathematics instead, got better in mathematics, though they did not make as much progress in reading. Hawthorne effects were controlled for in that the control group also received extra instruction (but in a different subject area). The study showed that extra tuition to these "bottom shelf" readers in the poorer part of the country, whether in reading or mathematics, produced significantly better outcomes than no tuition at all (Nicholson, Turner, \& Tse, 2009). Phonics tuition turned out to be somewhat more effective than whole language tuition, but they both seemed to be helpful. From this experience, I would argue that "raising the needle" in reading in South Auckland needs a range of strategies and resources, including long term extra tuition for those who are "at risk" - there is no one "magic bullet".

A final point is that we need to do much more scientific research on Māori literacy to find out what works best (Nicholson, 2006b, p. 7). Studies funded by the Ministry of Education have been worthy attempts, but each one has invited criticism because of design problematics. We desperately require more carefully-controlled studies. This is the only way our research base will expand and our understanding will move forward.

\section{Suggested Strategies}

Is there a way to make Māori children better than mediocre, to become the best readers in the world by 2020? If we are unable to introduce phonics to the classroom setting, what more can we do? Summer schools are worth considering (Tiruchittampalam \& Nicholson, 2008). In one study, where we taught phonics, the reading progress of decile 1 children who attended summer school was compared with that of a comparison group from the same school who did not. The results showed that the summer school children stayed about the same in reading achievement, but non-summer school children declined in reading achievement by about six months over the holiday break! We have other interesting data that suggest the opposite effect for children from high socioeconomic schools - over the school holidays (without any intervention at all) their reading improved (Tiruchittampalam, 2008). This suggests that summer schools are an important tool to prevent the "summer slide" for Māori children, perhaps even summer schools based on maraes. Another option is after-school reading instruction. We have found that small amounts of extra instruction can have a significant impact on poor readers (Nicholson, Turner, \& Tse, 2009; Nicholson \& Dymock, 2009). On the other hand an argument against summer and after-school instruction is that they are expensive and do not make much difference. Hattie (2009) reported that metaanalyses of summer schools in other countries have found very small effect sizes for disadvantaged children. Even so, Hattie noted that small gains could be critical for students who are already failing and for whom there is no substantive help.

It also seems clear that schools in low-decile areas will need additional specialist teachers who know how to train others in the skills of teaching phonological awareness and phonics. They need to be permanently based in schools, to coach, monitor, and to direct extra instruction toward pupils in the crucial junior school years and beyond. They can bring knowledge and experience, especially of the basic skills of literacy and numeracy, can provide tutoring to the hardest cases, and can act as role models and drivers of change. It would be a bonus if those teachers also had a good grasp of Te Reo.

How well informed are Māori parents about their children's reading levels? When I've run summer schools I have been surprised how many Māori and Pacific parents did not know how well their children were reading. If they knew they might try to do something more to help. The argument against giving totally honest feedback about children's 
progress is that it might result in an over-reaction from parents complaints to the School Board, perhaps requests for teacher discipline, even though the children's reading difficulties might have started long before. For this reason some schools might be reluctant to say explicitly that a child is struggling. A possible solution is to have accurate reporting, but to have it in a supportive setting where parents can get positive help for their children. For Māori children the most positive environment is the marae, and perhaps the marae could be used as a place for reporting on the progress of children and arranging support for them.

\section{Conclusion}

We can achieve equity in reading for Māori children by 2020, but we will need to revolutionise our delivery of services to them, by:

- introducing a more phonological way of teaching reading that complements the phonemic nature of Te Reo;

- making a long-term commitment to raising achievement in low decile schools, especially for Māori children;

- increasing the quantum of intervention help for Māori children, including after-school and summer programmes;

- appointing dedicated specialist teachers to schools where there are significant numbers of children who are struggling to read;

- providing clear and easy-to-understand reports to Māori parents about their children's reading progress; and

- designing and carrying out controlled studies to find more effective ways of closing the literacy gap.

Before concluding, it is necessary to mention one very positive development which has been in place for some time - Books in Homes. More than 5 million books have been given to children in low-decile schools where there are many Māori and Pacific children. They are called "Duffy books", after the originator of the programme, Alan Duff. Giving books to low-decile children is not going to close the literacy gap but it is extremely worthwhile, and Alan Duff is to be commended for his generous initiative. But much more is needed if we are to break through the glass ceiling that is holding back Māori children - and many other children who are struggling to read.

We need to keep reminding ourselves how important literacy is, how empty life can be without it and how angry it can make us not to have this skill. The description of Mr Crook in his run-down shop trying to learn to read in Bleak House (Dickens, 1853) brings this home so well:

Here on the head of an empty barrel stood on end were an ink-bottle, some old stumps of pens, and some dirty playbills; and against the wall, were pasted several large printed alphabets in several plain hands.

"What are you doing here?" asked my guardian.

"Trying to learn myself to read and write."

"And how do you get on?"

"Slow. Bad," returned the old man, impatiently. "It's hard at my time of life."

"It would be easier to be taught by someone," said my guardian.

"Aye, but they might teach me wrong!" returned the old man, with a wonderfully suspicious flash of his eye.

\section{Notes}

1. This article has been modified and redrafted from papers presented at the following conferences:

- 21st Century Education: The Waipareira way, Waitakere City, Auckland, April 2008;

- $\quad$ Nga Maata Waka 21st Century Education Summit, Nga Hau e Wha Marae, Christchurch, July 2008;

- Te AoHurihuri: Changing Dimensions of Tertiary Education, Mount Wellington, Auckland, October 2008;

- Manukau 21st Century Education Hui, Te Wananga o Aotearoa, Mangere, Auckland, November 2008.

2. Schools are rated by the Ministry of Education from 1 to 10 so that schools tapping areas where qualifications and incomes are lowest will be rated as decile 1 and schools where qualifications and incomes are highest will be decile 10

\section{References}

Bishop, R., Berryman, M., Cavanagh, T., \& Teddy, L. (2007). Te Kotahitanga Phase 3 Whanaungatanga: Establishing a culturally responsive pedagogy of relations in mainstream secondary school classrooms. Wellington: Ministry of Education.

Castle, J. M., Riach, J., \& Nicholson, T. (1994). Getting off to a better start in reading and spelling: The effects of phonemic awareness instruction within a whole language program. Journal of Educational Psychology, 86, 350-359. 
Chamberlain, M. (2006). Reading literacy in New Zealand: An overview of New Zealand's results from the Progress in International Reading Literacy Study (PIRLS) 2005/2006. Wellington: Ministry of Education.

Chapman, J. W., Tunmer, W. E., \& Prochnow, J. E. (1998a). An examination of the effectiveness of Reading Recovery. A longitudinal study. Research Report submitted to Ministry of Education. Palmerston North: Massey University.

Chapman, J. W., Tunmer, W. E., \& Prochnow, J. E. (1998b). Early reading-related skills and performance, reading self-concept, and the development of academic self-concept: A longitudinal study. Journal of Educational Psychology, 92, 703-708.

Clark, J. (2006). The gap between the highest and lowest school achievers: Philosophical arguments for downplaying teacher expectation theory. New Zealand Journal of Educational Studies, 41, 367-382.

Clay, M. M. (1982). Observing young readers. Auckland: Heinemann.

Dickens, C. (1853/1996). Bleak House. New York: Oxford University Press.

Elley, W. B. (1994, May). New Zealand reading programmes in an international context: Reflections on the IEA reading literacy survey. Paper presented at the meeting of the International Reading Association, Toronto.

English, C., Bareta, L., \& Winthrop, M. (2008). Literacy professional development project: Evidence of improved student outcomes. Wellington: Learning Media.

Gamse, B. C., Bloom, H. S., Kemple, J. J., \& Jacob, R. T., (2008). Reading First Impact Study: Interim Report (NCEE 2008-4016). Washington, DC: National Center for Education Evaluation and Regional Assistance, Institute of Education Sciences, U.S. Department of Education.

Gibbons, J. (1981). The effects of book experience on the responses of 4-year olds to text. Unpublished master's thesis, University of Waikato, Hamilton.

Gibbs, C. J., \& Nicholson, T. (1999). When you've heard it all before and still can't read. Effective School Practices, 17, 78-84.

Goodman, K. S. (1965). A linguistic study of cues and miscues in reading. Elementary English, 42, 639-643.
Glynn, T., Crooks, T., Bethune, N., Ballard, K., \& Smith, J. (1989). Reading Recovery in context. Wellington: Department of Education.

Gough, P. B. (1996, February). A pox on both your houses. Paper presented to Symposium on Integrated Direct Instruction in Reading, sponsored by the Language Arts Foundation of America and Oklahoma Schools, Oklahoma City.

Gough, P. B., \& Lee, C. H. (2007). A step toward early phonemic awareness: The effects of turtle talk training. Psychologia, 50, 54-66.

Half of Māori boys leave school with no qualification. (2007, February 12). New Zealand Herald.

Harker, R. (2003). External validity and the Pace research. New Zealand Journal of Educational Studies, 38, 245-247.

Harrison, C., \& Gough, P. B. (1996). Compellingness in reading research. Reading Research Quarterly, 31, 334-341.

Hattie, J. A. (2009). Visible learning: A synthesis of over 800 meta-analyses relating to achievement. London: Routledge.

Henson, N. (1991). Reading in the middle and upper primary school. Wellington: Ministry of Education.

Hughes, C. U. (1999). Teachers' perceptions of methods and practices employed in the teaching of reading and the language arts. Unpublished master's thesis, University of Auckland.

Johnston, R. S., \& Watson, J. E. (2007). A seven year study of the effects of synthetic phonics teaching on reading and spelling attainment. Insight 17. Edinburgh: Scottish Executive Education Department.

Lai, M. K., McNaughton, S., Amatuanai-Tuloa, M., Turner, R., \& Hsiao, S. (2009). Sustained acceleration of reading comprehension: The New Zealand experience. Reading Research Quarterly, 44, 30-56.

Lock, K. J., \& Gibson, J. K. (2008). Explaining Māori under-achievement in standardised reading tests: The role of social and individual characteristics. Kotuitui: New Zealand Journal of Social Sciences Online, $3,1-13$.

Maani, S. A. (2004). Why have Māori relative income levels deteriorated over time? The Economic Record, 80, 101-124.

Matthews, M. (1995). Challenging NZ science education (pp. 57-64). Palmerston North: Dunmore Press. 
McDowell, S., Cameron, M., Dingle, R., Gilmore, A., \& MacGibbon, L. (2007). Evaluation of the literacy professional development project. Wellington: Ministry of Education.

McNaughton, S., Phillips, G., \& McDonald, S. (2003). Profiling teaching and learning needs in beginning literacy instruction: The case of children in "low decile" schools in New Zealand. Journal of Literacy Research, 35, 703-730.

Ministry of Education. (1999). Literacy experts report. Wellington: Ministry of Education.

Ministry of Education. (2006). School leavers: 2005. Retrieved 23 October 2008 from: <www.educationcounts.govt.nz/statistics/pasifika_ education/schooling/school_leavers/school_leavers_2005 >.

Ministry of Education. (2008). School leavers with NCEA level 2 or above. Retrieved 23 October 2008 from:

$<$ www.educationcounts.govt.nz/statistics/data_cubes/ education_and_learning_outcomes/qualifications/3664 $>$.

Ministry of Social Development. (2008). 2008 The Social Report: School leavers with higher qualifications. Retrieved 23 October 2008 from: $<$ www.socialreport.msd.govt.nz/knowledge-skills/ school-leavers-higher-qualifications.html>.

Mullis, I. V., Martin, M. O., Gonzalez, E. J., \& Kennedy, A. M. (2003). PIRLS 2001 International Report: IEA's study of reading literacy achievement in primary schools. Chestnut Hill, MA: Boston College.

Mullis, I. V., Martin, M. O., Kennedy, A. M., \& Fory, P. (2007). PIRLS 2006 International Report. Boston, MA: TIMMS \& PIRLS International Study Centre, Lynch School of Education, Boston College.

Nash, R. (2003). One Pace forward two steps backward? New Zealand Journal of Educational Studies, 38, 249-254.

Nicholson, T. (1991). Do children read words better in context or lists? Journal of Educational Psychology, 83, 444-450.

Nicholson, T. (1997). Closing the gap on reading failure. In B. A. Blachman (Ed.), Foundations of reading acquisition and dyslexia (pp. 381-408). Mahwah, NJ: Lawrence Erlbaum.

Nicholson, T. (2003). Risk factors in learning to read. In B. R. Foorman (Ed.), Preventing and remediating reading difficulties (pp. 166-193). Baltimore, MD: York Press.
Nicholson, T. (2005). At the cutting edge: The importance of phonemic awareness in learning to read and spell. Wellington: New Zealand Council for Educational Research.

Nicholson, T. (2006a). Phonics handbook. Chichester, England: Wiley.

Nicholson, T. (2006b, A pril 21). Controlled research: Tom Nicholson calls for greater rigour in educational research. New Zealand Education Review.

Nicholson, T. (2008, May). The language, reading and writing development of children from different socioeconomic backgrounds in their first year of school. Paper presented to Israeli Literacy and Language Society, Tel Aviv.

Nicholson, T., \& Dymock, S. J. (2009). Zero to hero: The effects of after-school reading tuition for struggling readers. Manuscript submitted for publication.

Nicholson, T., \& Tunmer, W. E. (in press). Reading. In C. Rubie-Davies (Ed.), Educational Psychology: Concepts, research, and challenges. Abingdon, England: Routledge.

Nicholson, T., Turner, L., \& Tse, L. (2009, June). Phonics and whole language: Can they be friends? Looking at the effects of two different tutoring strategies for struggling readers in three disadvantaged schools over two years. Paper presented at meeting of the Society for the Scientific Study of Reading, Boston, Massachusetts.

Openshaw, R. (2007). Evaluation of Te Kotahitanga Phase 3. Wellington: Post Primary Teachers Association (PPTA).

Organisation for Economic Cooperation and Development. (1998). Overcoming failure at school. Paris: OECD.

Parr, C. J. (1963). Māori literacy 1843-1867. Journal of the Polynesian Society, 72, 211-234.

Pearson, P. D. (2004). The reading wars. Educational Policy, 18, 216-252.

Phillips, G., McNaughton, S., \& McDonald, S. (2004). Managing the mismatch: Enhancing early literacy progress for children with diverse language and cultural identities in mainstream urban schools in New Zealand. Journal of Educational Psychology, 96, 309-323.

Ramsay, P. D., Sneddon, D. G., Grenfell, J., \& Ford, I. (1981). Tomorrow may be too late: Schools with special needs in Mangere and Otara. Hamilton: University of Waikato. 
Scarborough, H., \& Dobrich, W. (1994). On the efficiency of reading to preschoolers. Developmental Review, 14, 245-302.

Simon, J. (Ed.). (1998). Nga Kura Māori. Auckland: Auckland University Press.

Smith, J., \& Elley, W. (1997). How children learn to read. Auckland: Longman.

Stanovich, K. E. (1986). Matthew effects in reading: Some consequences of individual differences in the acquisition of literacy. Reading Research Quarterly, 20, 360-406.

Strategy and System Performance. (2007). State of Education in New Zealand: 2007. Wellington: Ministry of Education.

Stuart, M. (1999). Getting ready for reading: Early phoneme awareness and phonics teaching improves reading and spelling in inner city second language learners. British Journal of Educational Psychology, 69, $587-605$.

Thompson, G. B. (1993). Reading instruction for the initial years in New Zealand schools. In G. B. Thompson, W. E. Tunmer, \& T. Nicholson (Eds.), Reading acquisition processes (pp. 148-154). Clevedon, England: Multilingual Matters.

Thompson, G. B. (2002). Teaching and the phonics debate: What can we learn? New Zealand Annual Review of Education, 11, 161-178.

Thorndike, R. (1973). Reading comprehension in 15 countries. New York: Wiley.

Tiruchittampalam, S. (2008, November). The summer slide in literacy. Paper presented at meeting of the New Zealand Association for Research in Education, Palmerston North.

Tiruchittamapalam, S., \& Nicholson, T. (2009). Summer schools and summer slides. Unpublished paper, Massey University, Auckland.

Toppo, G. (2008, May 2). Study: Reading First has little impact on kids' scores. USA Today, p. 4A.

Tunmer, W. E., Chapman, J. W., Ryan, H. A., \& Prochnow, J. E. (1998). The importance of providing beginning readers with explicit training in phonological processing skills. Australian Journal of Learning Disabilities, 3, 4-14.

Tunmer, W., Prochnow, J., \& Chapman, J. (2000). Science can inform educational practice: The case of literacy. New Zealand Annual Review of Education, 9, 133-156.
Tunmer, W. E., Chapman, J. W., \& Prochnow, J. E., (2003). Preventing negative Matthew effects in at-risk readers: A retrospective study. In B. R. Foorman (Ed.), Preventing and remediating reading difficulties (pp. 121-164). Baltimore, MD: York Press.

Tunmer, W. E., \& Nicholson, T. (in press). The development and teaching of word recognition skill. In P. D. Pearson et al. (Eds.), Handbook of reading research (Vol. 4). Mahwah, NJ: Lawrence Erlbaum.

Tunmer, W. E., Nicholson, T., Greaney, K. T., Prochnow, J. E., Chapman, J. W., \& Arrow, A. W. (2008). PIRLS before swine: A critique of the New Zealand literacy strategy. New Zealand Journal of Educational Studies, 43(2), 105-119.

Wagemaker, H. (Ed.). (1993). Achievement in reading literacy. New Zealand's performance in a national and international context. Wellington: Ministry of Education.

\section{The author}

Tom Nicholson is co-director of the Centre of Excellence for Research on Children's Literacy (CERCL) at Massey University, Auckland. He is a member of the International Reading Association Hall of Fame. 